\title{
Olprinone protects liver from ischemia reperfusion injury through oxidative stress prevention and protein kinase Akt activation
}

\begin{tabular}{|c|c|}
\hline Journal: & Canadian Journal of Physiology and Pharmacology \\
\hline Manuscript ID & cjpp-2017-0153.R1 \\
\hline Manuscript Type: & Article \\
\hline Date Submitted by the Author: & 11-Apr-2017 \\
\hline Complete List of Authors: & $\begin{array}{l}\text { Bejaoui, Mohamed; Universite de Monastir Faculte de Pharmacie de } \\
\text { Monastir, Unité de recherche Biologie et anthropologie moléculaire } \\
\text { appliquées au développement et à la santé (UR12ES11) } \\
\text { Zaouali, Mohamed Amine; Universite de Monastir Faculte de Pharmacie de } \\
\text { Monastir, Unité de recherche Biologie et anthropologie moléculaire } \\
\text { appliquées au développement et à la santé (UR12ES11) } \\
\text { Sakly, Rim; Universite de Monastir Faculte de Pharmacie de Monastir, Unité } \\
\text { de recherche Biologie et anthropologie moléculaire appliquées au } \\
\text { développement et à la santé (UR12ES11) } \\
\text { Ben Abdennebi, Hassen; Universite de Monastir Faculte de Pharmacie de } \\
\text { Monastir, Unité de recherche Biologie et anthropologie moléculaire } \\
\text { appliquées au développement et à la santé (UR12ES11) }\end{array}$ \\
\hline $\begin{array}{r}\text { Is the invited manuscript for } \\
\text { consideration in a Special } \\
\text { Issue?: }\end{array}$ & N/A \\
\hline Keyword: & $\begin{array}{l}\text { ischemia, reperfusion injury, Phosphodiesterase, Protein kinase B, } \\
\text { oxidative stress }\end{array}$ \\
\hline
\end{tabular}




\section{Olprinone protects liver from ischemia reperfusion injury through oxidative stress} prevention and protein kinase Akt activation

Mohamed Bejaoui, Mohamed Amine Zaouali, Rim Sakly, Hassen Ben Abdennebi

Research Unit (UR12ES11) "Molecular Biology and Anthropology Applied to Development and Health", Department of Physiology, Faculty of Pharmacy, University of Monastir, Monastir, Tunisia

Emails: Mohamed Bejaoui: bjaouiph@hotmail.fr

Mohamed Amine Zaouali: daminzaouali12@yahoo.fr

Rim Sakly: saklyrim@,outlook.com

Hassen Ben Abdennebi: hbenabdennebi@yahoo.fr

\section{Correspondence to:}

Mohamed Bejaoui, Department of Physiology, Faculty of Pharmacy, University of Monastir, Monastir, Tunisia

Tel: +21621976660

Fax: +21673461830

e-mail: bjaouiph@hotmail.fr 


\begin{abstract}
Liver ischemia reperfusion (IR) injury is inevitable in surgical procedures such as hepatic resection and liver transplantation. It represents a leading cause of liver graft dysfunction and primary non function after transplantation. Phosphodiesterase (PDE) inhibitors are emerging as effective drugs able to reduce IR damage. The aim of this study was to investigate the effect of selective PDE-3 inhibitor olprinone (Olp) against liver IR injury. Male Wistar rats were subjected to one hour of partial warm ischemia $(70 \%)$ followed by six hours of reperfusion. Before ischemia, rats were treated with saline (IR group), Olp (Olp group) or Olp with Akt inhibitor LY294002 (Olp + LY group). After reperfusion, hepatic injury (transaminase activities), mitochondrial damage (glutamate dehydrogenase activity), oxidative stress (malondialdehyde and glutathione concentrations and catalase and superoxide dismutase activities) as well as protein kinase Akt activation were evaluated. Rat treatment with Olp reduced liver injury, prevented mitochondrial damage, decreased lipid peroxidation and enhanced antioxidant enzymes. Also, Olp induced a significant activation in protein kinase Akt. Inhibition of Akt with LY294002 abolished all the protective effects of Olp. In conclusion, Olp treatment may be an effective strategy in reducing liver IR injury through oxidative stress prevention and Akt activation.
\end{abstract}

Key Words: Ischemia reperfusion injury, liver, olprinone, oxidative stress, Akt 
Les lésions d'ischémie-reperfusion (IR) sont inévitables dans certaines situations cliniques comme la résection et la transplantation hépatique. D'ailleurs, elles représentent la principale cause de la défaillance hépatique et la reprise fonctionnelle retardée du greffon en transplantation. Les phosphodiestérases (PDE), une famille d'enzymes responsables de l'inactivation de l'adénosine monophosphate cyclique (AMPc) et de la guanosine monophosphate cyclique (GMPc), sont impliquées dans la modulation de plusieurs voies de signalisation cellulaire protectrices contre les lésions d'IR. Le but de ce travail est d'étudier l'effet de l'olprinone (Olp), un inhibiteur sélectif de la PDE-3, contre ces lésions et d'évaluer l'implication de la protéine kinase B (Akt) dans cet effet. Des rats mâles Wistar ont été soumis à 1 heure d'ischémie chaude partielle (70\%), suivie de 6 heures de reperfusion. Avant l'induction de l'ischémie, les rats ont été traités avec du sérum physiologique (groupe IR), de l'Olp (groupe Olp) ou de 1'Olp avec LY294002, (un inhibiteur de Akt, groupe Olp + LY). Après la reperfusion, la cytolyse hépatique (activité des transaminases), la lésion mitochondriale (activité de la glutamate déshydrogénase), le stress oxydatif (concentrations du malondialdéhyde et du glutathion, et activités de la catalase et de la superoxyde dismutase) ont été évalués. Le traitement des rats par l’Olp diminue la cytolyse du foie, les dommages mitochondriaux, la peroxydation lipidique et améliore l'activité des enzymes antioxydantes. L'inhibition de l'Akt avec LY294002 aboli tous les effets protecteurs de l'Olp. En conclusion, l'Olp réduit les dommages dus à l'IR du foie en prévenant le stress oxydant et en modulant l'activation de l'Akt. 


\section{Introduction}

Ischemia reperfusion (IR) injury remains an inevitable and unresolved problem in liver surgery; it determines the viability of the hepatic tissue after resection, repair of trauma and liver transplantation (LT). It is well known that this multifactorial process inherent to every LT, is the main cause of initial poor function and primary non-function of liver allograft (Deschenes, 2013). In fact, the transient deprivation and return of blood flow and oxygen produce a concomitant release of reactive oxygen species (ROS) and reactive nitrogen species (RNS) which initiate a wide range of intracellular stress signaling. Oxidative and nitrosative stresses can induce lipid peroxidation of cell membranes, nuclear and mitochondrial DNA fragmentation, and sulfhydryl-mediated protein cross-linkage. The resulting injury ranges from the disturbance of hepatic microvascular homeostasis to organ dysfunction. Thereby, minimizing the deleterious effects of IR could increase significantly the results of LT and the recovery of liver after surgery. The first step towards this objective is a full understanding of the mechanisms involved in IR.

Within the last few years, many investigations have led to the identification of new potential targets such as ubiquitin proteasome system, sirtuins and phosphodiesterases (PDE) (Bejaoui et al. 2015; Soares et al. 2015; Bejaoui et al. 2014; Pantazi et al. 2014). PDE are a family of enzymes responsible for the degradation of cyclic adenosine monophosphate (cAMP) and cyclic guanosine monophosphate (cGMP), and thereby modulating various cellular signaling pathways. Recently, it has been shown that PDE inhibition by resveratrol protects from ischemic stroke by increasing cAMP level and subsequently activating the AMPK/SIRT1 signaling pathway (Wan et al. 2016). Moreover, Olprinone (Olp), a selective PDE-3 inhibitor, has been reported to protect 
liver against IR injury (Yamaguchi et al. 2010). A previous study showed that the supplementation of the university of Wisconsin (UW) preservation solution with Olp protected autotransplanted rat kidney (Zhang and Ma 2006). Moreover, Olp significantly reduced mortality in a model of IR of the gut (Crisafulli et al. 2010). These works have shown that the protective effects of Olp in the IR setting are related to its ability to induce cAMP increase. However, the cell signaling pathway involved in this effect is not fully elucidated.

The protein kinase Akt, also known as protein kinase $\mathrm{B}(\mathrm{PKB})$, is considered as an attractive therapeutic target due to its central role as a signaling protein leading to cell survival and prevention of apoptosis (Mullonkal and Toledo-Pereyra 2007). Several studies demonstrated that the modulation of Akt pathway could protect the liver from IR injury (Izuishi et al. 2006; Covington et al. 2016; Bejaoui et al. 2016). To our knowledge, the role of Olp on the modulation of Akt under hepatic IR condition is not yet known.

The aim of this study was to investigate the mechanism underlying the hepatoprotective effects of Olp against liver warm IR injury in rats, with a particular focus on oxidative stress and Akt activation.

\section{Materials and Methods}

\section{Animals}

Male Wistar rats weighing 300-350 g were used in this study. They were housed in a temperature and humidity controlled room under a constant 12-hour light/dark cycle, and they had free access to water and rat chow. This study was performed in accordance with European Union regulations (Directive 86/609 EEC). 


\section{Experimental model}

We used in this study the model of partial warm liver IR injury. Briefly, rats were anesthetized with an intraperitoneal injection of pentobarbital (5\%). After that, a midline laparotomy was performed and atraumatic vascular clips were used to interrupt the blood supply to the hepatic artery and portal vein of the left and median lobes $(70 \%$ ischemia) for 1 hour (Bejaoui et al. 2016). Reperfusion was initiated by removal of the clamps and laparotomy was closed. After 6 hours of reperfusion, animals were sacrificed and blood and tissue samples were collected. Sham operated rats underwent the same procedure without the vascular occlusion.

\section{Experimental Groups:}

Animals were randomly assigned into the following experimental groups, each containing 6 rats:

- Group 1 (Sham): Midline incision was performed and hepatic pedicle was dissected. Then, corresponding volume of saline was injected intravenously via the penile vein and laparotomy was closed.

- Group 2 (IR): Rats were pre-treated with saline intravenously and then subjected to 1 hour of ischemia followed by 6 hours of reperfusion.

- Group 3 (Olp): Same protocol as group 2 but rats were pre-treated with Olp (10 $\mu \mathrm{g} / \mathrm{kg}$ body weight, i.v. bolus) at $45 \mathrm{~min}$ before ischemia. The dose was set on the basis of a previous study (Matsumoto et al. 2009).

- Group $4(\mathrm{Olp}+\mathrm{LY})$ : Same protocol as group 3 but rats were pretreated with Akt inhibitor LY294002 (0.3 mg / $\mathrm{kg}$ body weight, i.v. bolus) at $5 \mathrm{~min}$ before Olp treatment (Matsumoto et al. 2009). 


\section{Transaminase measurement}

Plasma levels of alanine aminotransferase (ALT) and aspartate amino transferase (AST) were measured using a commercial kit from DiaSys (Diagnostic System, Germany) following supplier's instructions. Briefly, blood samples were centrifuged at $4{ }^{\circ} \mathrm{C}$ for 10 min at $3000 \mathrm{rpm}$. Following, $100 \mu \mathrm{L}$ of plasma were added to the substrate provided by the commercial kit and then transaminase levels were determined at $340 \mathrm{~nm}$ with an UV spectrometer.

Glutamate dehydrogenase activity

Glutamate dehydrogenase $(\mathrm{GLDH})$ is an enzyme present predominantly in the mitochondria of the hepatocytes (Ozer et al. 2008). The increase of its activity indicates mitochondrial damage (Ozer et al 2008). GLDH activity in the plasma was determined using a commercial kit (GLDH, Randox laboratories Ltd., Crumlin, UK) following manufacturer's protocol.

\section{Lipid peroxidation assessment:}

Lipid peroxidation was used as an indirect index of the oxidative stress induced by reactive oxygen species. It was evaluated by measuring malondialdehyde (MDA) formation in liver tissue using the thiobarbiturate reaction at $530 \mathrm{~nm}$ (Deng et al. 2016).

\section{Measurement of the antioxidant enzymes activities in the hepatic tissue}

The total superoxide dismutase ( $\mathrm{Cu}-\mathrm{Zn}$ SOD and Mn SOD) activity was assessed by following the inhibition of pyrogallol oxidation according to the method of Marklund and Marklund (Marklund and Marklund 1974). It was measured at $420 \mathrm{~nm}$ and expressed as $\mathrm{U} / \mathrm{mg}$ protein (one unit of SOD was defined as the enzyme amount causing $50 \%$ inhibition of pyrogallol oxidation). The glutathione peroxidase (GPX) activity was quantified by measuring the decrease in absorbance at $412 \mathrm{~nm}$ of reduced glutathione 
(GSH) in the presence of $\mathrm{H}_{2} \mathrm{O}_{2}$ as reported by Flohe and Gunzler (Flohe and Gunzler 1984). It was expressed as $\mu \mathrm{mol}$ of oxidized $\mathrm{GSH} / \mathrm{min} / \mathrm{mg}$ protein. The catalase (CAT) activity was measured using the method of Claiborne (Claiborne 1985), which consists of following the decomposition rate of $\mathrm{H}_{2} \mathrm{O}_{2}$ spectrophotometrically at $240 \mathrm{~nm}$. It was expressed as $\mu \mathrm{mol} \mathrm{H}_{2} \mathrm{O}_{2}$ decomposed/min/mg protein.

\section{Western blot analysis:}

Liver tissue (200 mg) was homogenized in HEPES buffer as previously described (Bejaoui et al. 2014), and then $50 \mu \mathrm{g}$ of protein were separated on $8 \%$ SDS-PAGE gels and transferred to polyvinylidene difluoride (PVDF) membranes. Membranes were incubated overnight at $4^{\circ} \mathrm{C}$ using anti-phosphorylated Akt, (Cell Signaling Technology Inc., catalogue number \#9272), anti-Akt (Cell Signaling Technology Inc., catalogue number \#9271) and anti- $\beta$-actin (Sigma Chemical, St. Louis, MO, USA). Afterwards, the rabbit secondary antibody was added for 1 hour at room temperature and membranes were developed using the enhanced chemiluminescence reagents from Avision (Advansta, Menlo Park, CA, USA). Signals were developed in films and quantified by measuring densitometry using the Quantity One software for images analysis.

\section{Statistical analysis:}

Data are expressed as means \pm standard deviation (SD) and were compared statistically by the one-way analysis of variance (ANOVA), followed by the Newman-Keuls test (Graph Pad Prism software). $P<0.05$ was considered significant. 


\section{Results}

We evaluated whether Olp, a PDE-3 inhibitor, could protect rat liver against IR injury and whether its effect could be mediated by the Akt pathway. As shown in Figures 1A and 1B, IR group led to a significant increase in transaminase levels compared to sham group, which was prevented when animals were pretreated with intravenous injection of Olp at $10 \mu \mathrm{g} / \mathrm{kg}$. Interestingly, the protective effect was abolished when LY294002 at $0.3 \mathrm{mg} / \mathrm{kg}$ was administered before Olp treatment. Treatment of sham operated rats by LY294002 didn't result in any liver damage (data not shown).

Given the key role played by mitochondria in IR injury, we measured GLDH activity to assess mitochondrial damage after 6 hours of reperfusion. As indicated in Figure 2, Olp preconditioning decreased significantly GLDH activity. By contrast, pre-treatment with Akt inhibitor inhibited the protective effect of Olp.

It is well known that hepatic damage after reperfusion is associated in part with oxidative stress and ROS generation; therefore, we evaluated the effects of Olp on lipid peroxidation and antioxidant enzymes status by measuring CAT, SOD and GPX activities. As shown in Figure 3, all oxidative stress parameters were significantly impaired as compared to shams. Olp treatment decreased significantly MDA levels and promoted CAT and SOD activities. No significant difference was found regarding GPX although a tendency towards an increase was observed when compared to IR group (Figure 3D). Importantly, Akt inhibitor treatment abrogated the protective effect of Olp.

Finally, we performed Western blot analysis of the protein kinase Akt to provide molecular basis regarding its implication in the mechanism of action of Olp. We found that Olp treatment induced a significant increase in Akt phosphorylation when 
compared to IR group. As expected, Akt inhibition by LY294002 administration prior to Olp treatment prevented the protein kinase activation (Figure 4).

\section{Discussion}

IR injury is the main cause of primary liver dysfunction and graft failure after liver resection and LT (Deschenes 2013). The development of effective strategy to reduce the deleterious effects of IR is an urgent need in order to overcome the complication associated with these surgical procedures. Olp, a selective PDE-3 inhibitor, has been shown to protect the gut, kidney, liver and heart against IR damage (Yamaguchi et al. 2010; Di Paola et al. 2011; Crisafulli et al. 2010; Mizutani et al 2005). An antiinflammatory effect and an improvement of the microcirculation that are mediated by the elevation of intracellular cAMP levels are considered to be the mechanisms underlying organ protection (Di Paola et al. 2011; Mizutani et al. 2005; Soares et al. 2015). Here, we demonstrated that Olp protects rat liver against IR injury through oxidative stress prevention and the activation of Akt protein.

In this work we have used Olp, a PDE type 3 selective inhibitor, because of its proven beneficial effects against ischemic liver damage (Yamaguchi et al. 2010). However, PDE type 5 inhibitor sildenafil has also been shown to protect against IR in many experimental models (Wang et al. 2015; Inan et al. 2013; Savvanis et al. 2014; Zahran et al. 2015; Mohey et al. 2016). Whether Olp and sildenafil involved different mechanism of action is not known. Therefore, it would be very interesting in further study to compare the effect of the two families of inhibitors and to investigate their differential mechanism or the synergic action. It is well known that mitochondrial dysfunction is an important factor of IR injury (Go et al. 2015). The onset of the mitochondrial permeability transition (MPT) was implicated in cell death associated with IR (Ong et al. 2015; Baines 2009; Liu et al. 2015). Moreover, it has been shown 
that cardioprotection induced by Olp involves MPT inhibition during early reperfusion (Tosaka et al. 2007). In line with this, our results showed that Olp preconditioning prevents mitochondrial damage.

Given that mitchochondrial dysfunction leads to ROS production (Serviddio et al. 2010), we evaluated the oxidative stress status after reperfusion. We found that Olp decreased oxidative stress as revealed by the reduction in lipid peroxidation and the activation of the major antioxidant enzymes SOD and CAT. In fact, the antioxidant effect of PDE inhibitors has been well reported. For instance, PDE-5 inhibitors decreased oxidative stress and reduced ischemic damage in heart and kidney (Kucuk et al. 2012; Koka et al. 2013). Moreover, resveratrol, a strong antioxidant polyphenol, has been shown recently to provide neuroprotection during ischemia by inhibiting PDEs (Wan et al. 2016).

In a previous report, Tosaka et al. have shown that the use PI3K-Akt inhibitor wortamine prevented the cardioprotective effect of Olp during early reperfusion, but there was no molecular evidence indicating that Olp activated the Akt protein kinase (Tosaka et al. 2007). In this study, our results have shown that the use of PI3K-Akt inhibitor LY294002 abolished Olp hepatoprotective effect. Furthermore, the treatment of sham operated rats with Akt inhibitor didn't result in any liver injury which confirms that the deleterious effects of Akt inhibitor LY294002 are related to Akt inhibition rather than a systemic effect of the drug (data not shown). Also, Western blot analysis has shown that Olp increased Akt phosphorylation which was reduced by the use of Akt inhibitor. Interestingly, the inhibition of Akt reduced antioxidant enzymes activities suggesting that Akt upregulation prevented oxidative stress. In line with this, it has been shown recently that the activation of Akt pathway by hydroxytyrosol induced a reduction of oxidative stress during myocardial IR (Pei et al. 2016). 
It is well known that steatotic livers are more vulnerable to ischemic damage than normal ones. In fact, hepatic steatosis is associated with significant morbidity and mortality after liver resection and transplantation (Chu et al. 2015). Moreover, it has been described that hepatocytes with fatty infiltration develop massive necrosis after IR injury, instead of apoptosis observed in non-steatotic livers (Fernandez et al. 2004). This fact may be due to low ATP production and dysfunction of regulators of apoptosis (Bcl2, Bcl-xL, and Bax), and may explain why caspase inhibition, a highly protective strategy in non-steatotic livers, had no effects on hepatocyte injury in steatotic livers (Selzner et al. 2000). These data are confirmed by the results of another clinical investigation, i.e., Serum Bcl-2 concentrations in overweight-obese subjects with nonalcoholic fatty liver disease (Tarantino et al. 2011). In our study, we have found that Olp reduced ischemic damage in normal livers through mechanism implicated in the high vulnerability of steatotic liver towards IR injury such as oxidative stress, mitochondrial damage and the activation of prosurvival pathways. From this perspective, we suggest that Olp may be considered as a drug candidate that satisfies the stringent requirement of steatotic livers.

\section{Conclusion}

Taken together, our results show that PDE-3 inhibitor Olp protects the liver against IR damage. The protective effect is associated with a reduction of oxidative stress and the activation of Akt. Based on these findings, we speculate that Olp would be relevant in clinical setting to achieve better outcomes in hepatic surgery.

\section{Conflict of Interests}


The author(s) declare(s) that there is no conflict of interest regarding the publication of this paper. 


\section{References}

BAINES, C. P. 2009. The mitochondrial permeability transition pore and ischemiareperfusion injury. Basic Res Cardiol, 104, 181-8.

BEJAOUI, M., PANTAZI, E., CALVO, M., FOLCH-PUY, E., SERAFIN, A., PASUT, G., PANiSEllo, A., ADAM, R. \& ROSEllO-CATAFAU, J. 2016. Polyethylene Glycol Preconditioning: An Effective Strategy to Prevent Liver Ischemia Reperfusion Injury. Oxid Med Cell Longev, 2016, 9096549.

BEJAOUI, M., PANTAZI, E., FOLCH-PUY, E., BAPTISTA, P. M., GARCIA-GIL, A., ADAM, R. \& ROSELLO-CATAFAU, J. 2015. Emerging concepts in liver graft preservation. World J Gastroenterol, 21, 396-407.

BEJAOUI, M., ZAOUALI, M. A., FOLCH-PUY, E., PANTAZI, E., BARDAGGORCE, F., CARBONELl, T., OLIVA, J., RIMOLA, A., ABDENNEBI, H. B. \& ROSELlO-CATAFAU, J. 2014. Bortezomib enhances fatty liver preservation in Institut George Lopez-1 solution through adenosine monophosphate activated protein kinase and Akt/mTOR pathways. J Pharm Pharmacol, 66, 62-72.

CLAIBORNE, A. 1985. Catalase activity. In: GREENWALD, R. A. (ed.) $C R C$ handbook of methods in oxygen radical research. CRC Press, Boca Raton, FL, USA.

COVInGtON, S. M., BAULER, L. D. \& TOLEDO-PEREYRA, L. H. 2016. Akt: A Therapeutic Target in Hepatic Ischemia-Reperfusion Injury. J Invest Surg, 1-9.

CRISAFUlli, C., MAZZON, E., GALUPPO, M., PATERNITI, I., CAMINITI, R. \& CUZZOCREA, S. 2010. Olprinone attenuates the development of ischemia/reperfusion injury of the gut. Intensive Care Med, 36, 1235-47. 
CHU, M. J., DARE, A. J., PHILliPS, A. R. \& BARTLETT, A. S. 2015. Donor Hepatic Steatosis and Outcome After Liver Transplantation: a Systematic Review. $J$ Gastrointest Surg, 19, 1713-24.

DENG, W. S., XU, Q., LIU, Y. E., JIANG, C. H., ZHOU, H. \& GU, L. 2016. Effects of melatonin on liver function and lipid peroxidation in a rat model of hepatic ischemia/reperfusion injury. Exp Ther Med, 11, 1955-1960.

DESCHENES, M. 2013. Early allograft dysfunction: causes, recognition, and management. Liver Transpl, 19 Suppl 2, S6-8.

DI PAOLA, R., MAZZON, E., PATERNITI, I., IMPELLIZZERI, D., BRAMANTI, P. \& CUZZOCREA, S. 2011. Olprinone, a PDE3 inhibitor, modulates the inflammation associated with myocardial ischemia-reperfusion injury in rats. Eur J Pharmacol, 650, 612-20.

FERNANDEZ, L., CARRASCO-CHAUMEL, E., SERAFIN, A., XAUS, C., GRANDE, L., RIMOLA, A., ROSELlO-CATAFAU, J. \& PERALTA, C. 2004. Is ischemic preconditioning a useful strategy in steatotic liver transplantation? Am J Transplant, 4, 888-99.

FLOHE, L. \& GUNZLER, W. A. 1984. Assays of glutathione peroxidase. Methods Enzymol, 105, 114-21.

GO, K. L., LEE, S., ZENDEJAS, I., BEHRNS, K. E. \& KIM, J. S. 2015. Mitochondrial Dysfunction and Autophagy in Hepatic Ischemia/Reperfusion Injury. Biomed Res Int, 2015, 183469.

INAN, M., UZ, Y. H., KIZILAY, G., TOPCU-TARLADACALISIR, Y., SAPMAZMETIN, M., AKPOLAT, M. \& AYDOGDU, N. 2013. Protective effect of sildenafil on liver injury induced by intestinal ischemia/reperfusion. $J$ Pediatr Surg, 48, 1707-15. 
IZUISHI, K., TSUNG, A., HOSSAIN, M. A., FUJIWARA, M., WAKABAYASHI, H., MASAKI, T., BILLIAR, T. R. \& MAETA, H. 2006. Ischemic preconditioning of the murine liver protects through the Akt kinase pathway. Hepatology, 44, 573-80.

KOKA, S., DAS, A., SALLOUM, F. N. \& KUKREJA, R. C. 2013. Phosphodiesterase-5 inhibitor tadalafil attenuates oxidative stress and protects against myocardial ischemia/reperfusion injury in type 2 diabetic mice. Free Radic Biol Med, 60, $80-8$.

KUCUK, A., YUCEL, M., ERKASAP, N., TOSUN, M., KOKEN, T., OZKURT, M. \& ERKASAP, S. 2012. The effects of PDE5 inhibitory drugs on renal ischemia/reperfusion injury in rats. Mol Biol Rep, 39, 9775-82.

LIU, L. F., QIAN, Z. H., QIN, Q., SHI, M., ZHANG, H., TAO, X. M. \& ZHU, W. P. 2015. Effect of melatonin on oncosis of myocardial cells in the myocardial ischemia/reperfusion injury rat and the role of the mitochondrial permeability transition pore. Genet Mol Res, 14, 7481-9.

MARKLUND, S. \& MARKLUND, G. 1974. Involvement of the superoxide anion radical in the autoxidation of pyrogallol and a convenient assay for superoxide dismutase. Eur J Biochem, 47, 469-74.

MATSUMOTO, S., CHO, S., TOSAKA, S., URESHINO, H., MAEKAWA, T., HARA, T. \& SUMIKAWA, K. 2009. Pharmacological preconditioning in type 2 diabetic rat hearts: the roles of mitochondrial ATP-sensitive potassium channels and the phosphatidylinositol 3-kinase-Akt pathway. Cardiovasc Drugs Ther, 23, 263-70.

MIZUTANI, A., MURAKAMI, K., OKAJIMA, K., KIRA, S., MIZUTANI, S., KUDO, K., TAKATANI, J., GOTO, K., HATTORI, S. \& NOGUCHI, T. 2005. 
Olprinone reduces ischemia/reperfusion-induced acute renal injury in rats through enhancement of cAMP. Shock, 24, 281-7.

MOHEY, V., SINGH, M., PURI, N., KAUR, T., PATHAK, D. \& SINGH, A. P. 2016. Sildenafil obviates ischemia-reperfusion injury-induced acute kidney injury through peroxisome proliferator-activated receptor gamma agonism in rats. $J$ Surg Res, 201, 69-75.

MULLONKAL, C. J. \& TOLEDO-PEREYRA, L. H. 2007. Akt in ischemia and reperfusion. J Invest Surg, 20, 195-203.

ONG, S. B., SAMANGOUEI, P., KALKHORAN, S. B. \& HAUSENLOY, D. J. 2015. The mitochondrial permeability transition pore and its role in myocardial ischemia reperfusion injury. $J$ Mol Cell Cardiol, 78, 23-34.

OZER, J., RATNER, M., SHAW, M., BAILEY, W. \& SCHOMAKER, S. 2008. The current state of serum biomarkers of hepatotoxicity. Toxicology, 245, 194-205.

PANTAZI, E., ZAOUALI, M. A., BEJAOUI, M., SERAFIN, A., FOLCH-PUY, E., PETEGNIEF, V., DE VERA, N., ABDENNEBI, H. B., RIMOLA, A. \& ROSELLO-CATAFAU, J. 2014. Silent information regulator 1 protects the liver against ischemia-reperfusion injury: implications in steatotic liver ischemic preconditioning. Transpl Int.

PEI, Y. H., CHEN, J., XIE, L., CAI, X. M., YANG, R. H., WANG, X. \& GONG, J. B. 2016. Hydroxytyrosol Protects against Myocardial Ischemia/Reperfusion Injury through a PI3K/Akt-Dependent Mechanism. Mediators Inflamm, 2016, 1232103.

SAVVANIS, S., NASTOS, C., TASOULIS, M. K., PAPOUTSIDAKIS, N., DEMONAKOU, M., KARMANIOLOU, I., ARKADOPOULOS, N., SMYRNIOTIS, V. \& THEODORAKI, K. 2014. Sildenafil attenuates 
hepatocellular injury after liver ischemia reperfusion in rats: a preliminary study. Oxid Med Cell Longev, 2014, 161942.

SELZNER, M., RUDIGER, H. A., SINDRAM, D., MADDEN, J. \& CLAVIEN, P. A. 2000. Mechanisms of ischemic injury are different in the steatotic and normal rat liver. Hepatology, 32, 1280-8.

SERVIDDIO, G., BELLANTI, F., SASTRE, J., VENDEMIALE, G. \& ALTOMARE, E. 2010. Targeting mitochondria: a new promising approach for the treatment of liver diseases. Curr Med Chem, 17, 2325-37.

SOARES, L. M., PRICKAERTS, J., MILANI, H., DEL BEL, E., STEINBUSCH, H. W. \& DE OLIVEIRA, R. M. 2015. Phosphodiesterase Inhibition as a Therapeutic Target for Brain Ischemia. CNS Neurol Disord Drug Targets, 14, 1012-23.

TARANTINO, G., SCOPACASA, F., COLAO, A., CAPONE, D., TARANTINO, M., GRIMALDI, E. \& SAVASTANO, S. 2011. Serum Bcl-2 concentrations in overweight-obese subjects with nonalcoholic fatty liver disease. World $J$ Gastroenterol, 17, 5280-8.

TOSAKA, S., MAKITA, T., TOSAKA, R., MAEKAWA, T., CHO, S., HARA, T., URESHINO, H. \& SUMIKAWA, K. 2007. Cardioprotection induced by olprinone, a phosphodiesterase III inhibitor, involves phosphatidylinositol-3-OH kinase-Akt and a mitochondrial permeability transition pore during early reperfusion. $J$ Anesth, 21, 176-80.

WAN, D., ZHOU, Y., WANG, K., HOU, Y., HOU, R. \& YE, X. 2016. Resveratrol provides neuroprotection by inhibiting phosphodiesterases and regulating the cAMP/AMPK/SIRT1 pathway after stroke in rats. Brain Res Bull, 121, 255-62. 
WANG, G., ZHANG, Q., YUAN, W., WU, J. \& LI, C. 2015. Sildenafil Protects against Myocardial Ischemia-Reperfusion Injury Following Cardiac Arrest in a Porcine Model: Possible Role of the Renin-Angiotensin System. Int J Mol Sci, 16, 27015-31.

YAMAGUCHI, K., KAWAHARA, T., KUMAKURA, S., HUA, J., KUGIMIYA, T., NAGAOKA, I. \& INADA, E. 2010. Effect of olprinone, a phosphodiesterase III inhibitor, on hepatic ischemia-reperfusion injury in rats. Shock, 33, 436-41.

ZAHRAN, M. H., HUSSEIN, A. M., BARAKAT, N., AWADALLA, A., KHATER, S., HARRAZ, A. \& SHOKEIR, A. A. 2015. Sildenafil activates antioxidant and antiapoptotic genes and inhibits proinflammatory cytokine genes in a rat model of renal ischemia/reperfusion injury. Int Urol Nephrol, 47, 1907-15.

ZHANG, Y. \& MA, Q. 2006. The enhancement of cellular cAMP with olprinone protects autotransplanted rat kidney against cold ischemia-reperfusion injury. Transplant Proc, 38, 1580-3. 


\section{Figures Legend}

Figure 1: Hepatic injury after ischemia reperfusion. Olp at $10 \mu \mathrm{g} / \mathrm{kg}$ decreases AST (a) and ALT (b) levels which was prevented by LY294002. Data represent mean \pm SD. ${ }^{*} P<0.05$ vs Sham, ${ }^{\#} P<0.05$ vs IR, ${ }^{+} P<0.05$ vs OLP.

Figure 2: Mitochondrial damage after liver ischemia reperfusion. Olprinone decreases glutamate dehydrogenase (GLDH) after 6 hours of reperfusion. The treatment by Akt inhibitor LY294002 abolished the protective effect of olprinone. Data represent mean \pm SD. ${ }^{*} P<0.05$ vs Sham, ${ }^{\#} P<0.05$ vs IR, ${ }^{+} P<0.05$ vs OLP.

\section{Figure 3: Effect of olprinone on lipid peroxidation and antioxidant enzymes.} Olprinone decreased malondialdehyde (MDA) (a) and enhanced the activities of catalase (CAT) (b), superoxide dismutase (SOD) (c) and glutathione peroxidase (GPx) (d). All these effects are prevented by LY294002 treatment. Data represent mean \pm SD. ${ }^{*} P<0.05$ vs Sham, ${ }^{\#} P<0.05$ vs IR, ${ }^{+} P<0.05$ vs OLP.

Figure 4: Effect of olprinone on Akt activation. Olprinone preconditioning enhances Akt activation which was inhibited by LY. Western blot and densitometric analysis of phosphorylated Akt / total Akt. Data represent mean \pm SD. ${ }^{*} P<0.05$ vs Sham, ${ }^{\#} P<$ 0.05 vs IR, ${ }^{+} P<0.05$ vs OLP. 
(a)

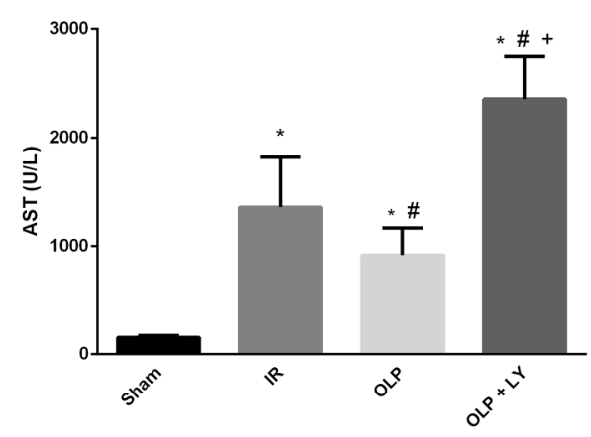

(b)

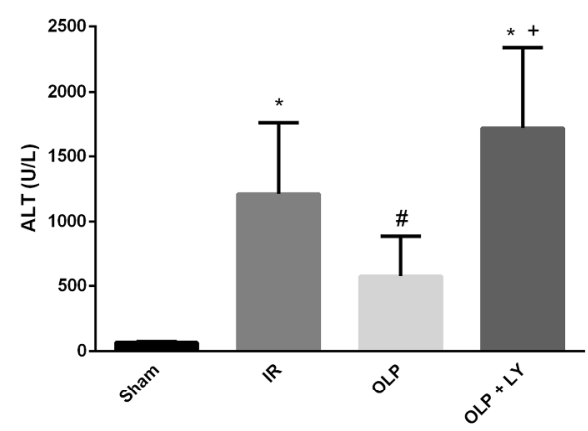

Figure 1: Hepatic injury after ischemia reperfusion. Olp at $10 \mu \mathrm{g} / \mathrm{kg}$ decreases AST (a) and ALT (b) levels which was prevented by LY294002. Data represent mean \pm SD. $* P<0.05$ vs Sham, \# P 0.05 vs IR, $+P$ $<0.05$ vs OLP. 


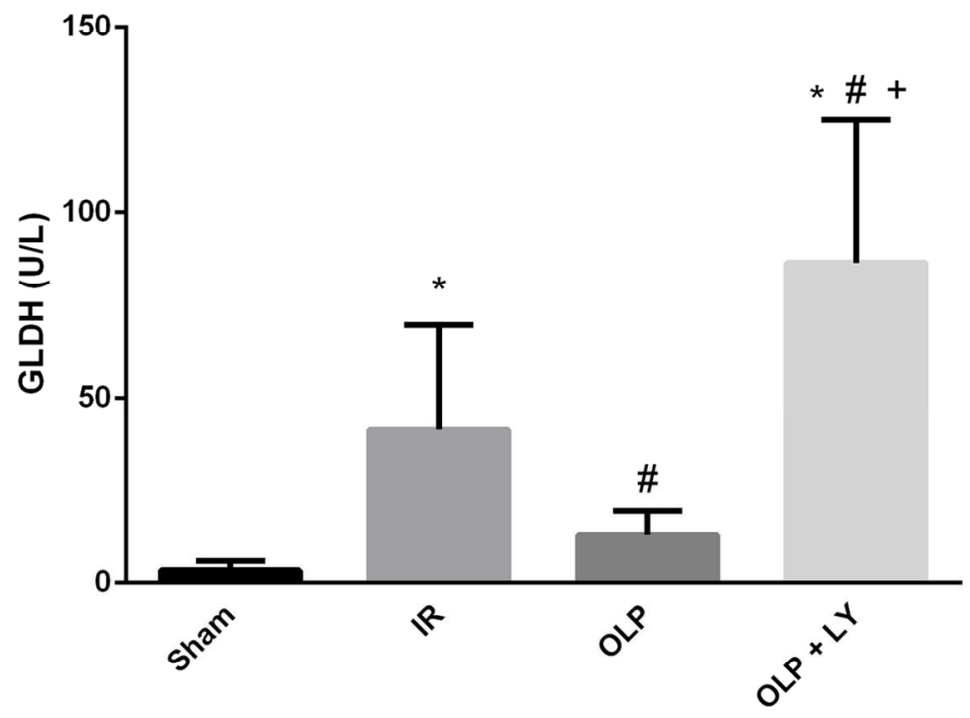

Figure 2: Mitochondrial damage after liver ischemia reperfusion. Olprinone decreases glutamate dehydrogenase (GLDH) after 6 hours of reperfusion. The treatment by Akt inhibitor LY294002 abolished the protective effect of olprinone. Data represent mean \pm SD. $* P<0.05$ vs Sham, \# $P<0.05$ vs IR, $+P<$ 0.05 vs OLP. 
(a)

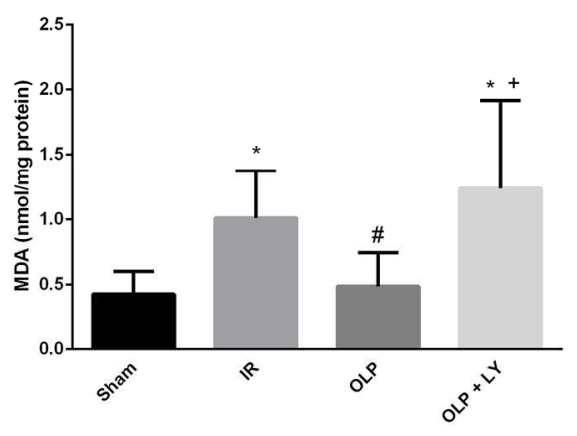

(c)

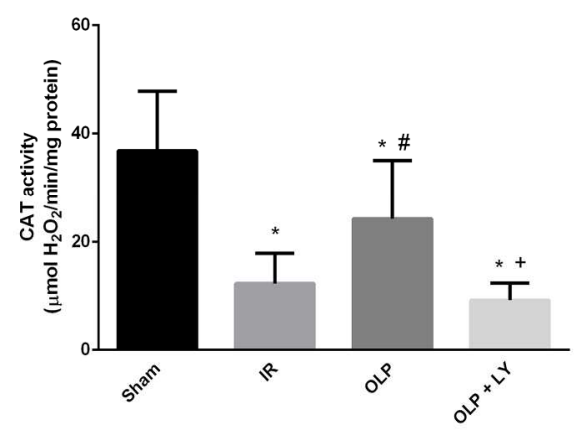

(b)

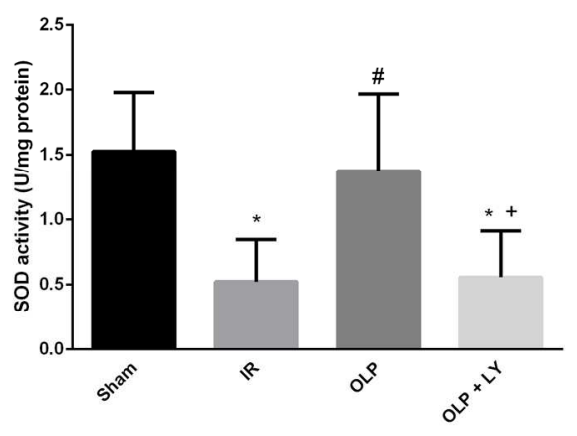

(d)

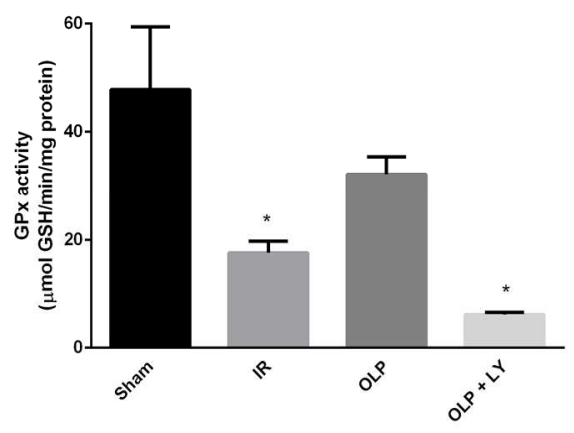

Figure 3: Effect of olprinone on lipid peroxidation and antioxidant enzymes. Olprinone decreased malondialdehyde (MDA) (a) and enhanced the activities of catalase (CAT) (b), superoxide dismutase (SOD) (c) and glutathione peroxidase (GPX) (d). All these effects are prevented by LY294002 treatment. Data represent mean $\pm S D$. $* P<0.05$ vs Sham, \# $P<0.05$ vs IR, $+P<0.05$ vs OLP. 

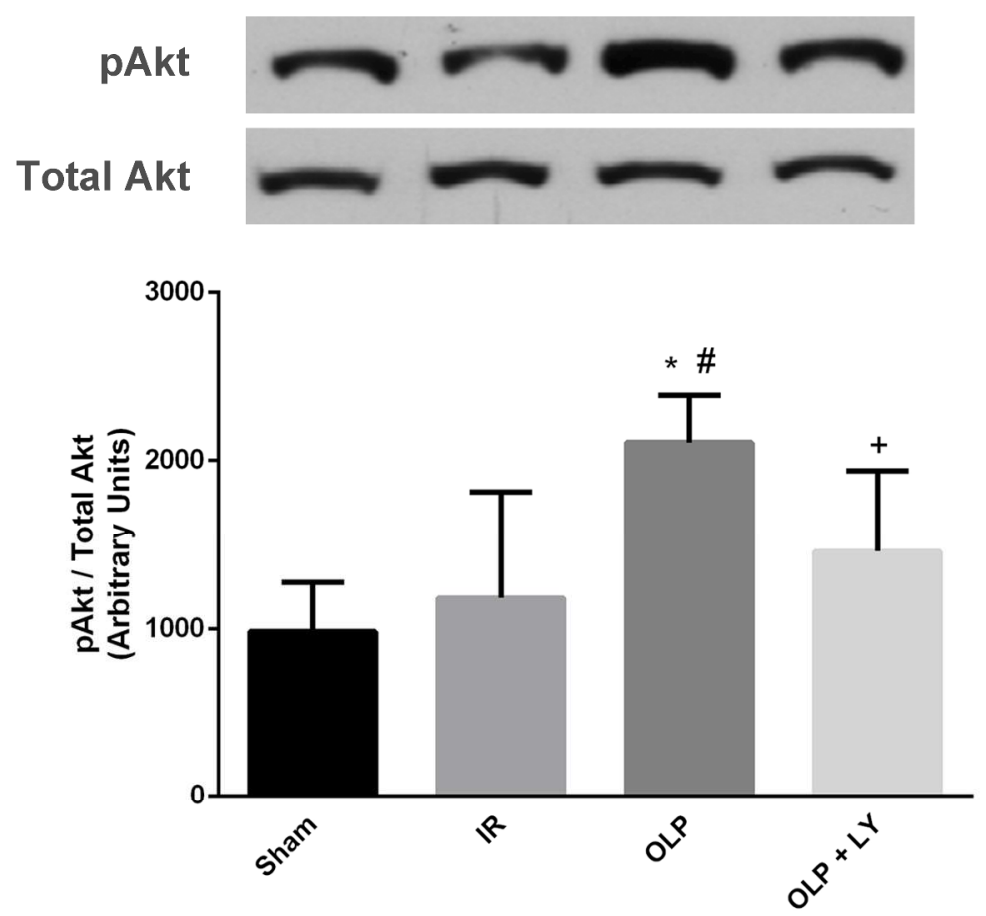

Figure 4: Effect of olprinone on Akt activation. Olprinone preconditioning enhances Akt activation which was inhibited by LY. Western blot and densitometric analysis of phosphorylated Akt / total Akt. Data represent mean \pm SD. $* P<0.05$ vs Sham, \# P 0.05 vs IR, $+P<0.05$ vs OLP. 